\author{
Antonina Pawłowska \\ Uniwersytet Łódzki \\ ORCID 0000-0003-3467-4583 \\ DOI https://doi.org/10.21697/ucs.2021.27.1.03
}

\title{
IRISH TRAVELLERS, KOTLARZE, WŁÓCZĘDZY, „SZKODNIKI” - HISTORYCZNE ŹRÓDŁA WYKLUCZENIA
}

\author{
Irish Travellers, tinkers, vagrants, “pests” - historical sources of exclusion
}

\begin{abstract}
Streszczenie
Celem artykułu jest analiza zagadnień związanych z naukowymi badaniami nad historią Irish Travellers, ze szczególnym uwzględnieniem funkcjonujących w obiegu naukowym teorii na temat pochodzenia tej grupy etnicznej. Rozważania historiograficzne nad problematyką badań w tym zakresie oraz metodologią stosowaną przez badaczy w XX wieku zostały skonfrontowane ze społecznym i politycznym znaczeniem tych badań. Analiza źródłowa i porównawcza pozwoliły na określenie ich wpływu na działania państwa irlandzkiego oraz scharakteryzowanie problemów metodologicznych pojawiających się podczas próby zbadania owego zagadnienia. W efekcie dokonana została periodyzacja pojawiających się teorii naukowych na powyższy temat. Artykuł stanowi też podsumowanie wniosków funkcjonujących w anglosaskim obiegu naukowym i próbę wprowadzenia tematu do dyskursu polskiego.
\end{abstract}

Słowa kluczowe: Irish Travellers, irlandzka historiografia, wykluczenie społeczne, metodologia historii, Kolekcja Folkloru, Irlandzka Komisja Folkloru

\begin{abstract}
The goal of the article is to analyse the issues of scientific research on the history of Irish Travellers, with emphasis put on theories on this group's origin that circulate within academic circles. The historiographic considerations on the subject and methodology applied by scholars in the 20th century are being confronted with their social and political significance. Source analysis, combined with comparative studies allowed a description of the relation between Ireland's actions and the results of academic studies, as well as the characterization of methodological issues arising when attempting to study such an issue. The above mentioned process resulted in the periodization of scientific theories on this topic. In addition, the article serves as an overview of the findings circulating in - Anglosaxon academia, and an attempt to popularise the topic in Polish academic circles.
\end{abstract}

Keywords: Irish Travelers, Irish historiography, social exclusion, historical method, Folklore Collection, Irish Folklore Commission

\section{Wprowadzenie}

Problematyka badań nad grupą etniczną Irish Travellers stanowi w polskim obiegu naukowym swego rodzaju nowość, jednak na gruncie brytyjskim i irlandzkim jest ona przedmiotem nie tylko działań naukowców z różnorodnych ośrodków, ale również burzliwej debaty społecznej. Warto więc poddać analizie sposób, w jaki badania historyczne, antropologiczne i socjologiczne wchodzą w relację z polityką i jak mogą zostać wykorzystane w debacie publicznej. 
Celem niniejszego artykułu jest gruntowna analiza zagadnień związanych z naukowymi badaniami nad historią Irish Travellers - grupy etnicznej zamieszkującej, między innymi, Irlandię. Omówiona zostanie nie tylko jej relacja z irlandzkim państwem i społeczeństwem, ale również historia badań nad jej pochodzeniem oraz metodologii badań prowadzonych w XX wieku. Analiza ta zostanie przedstawiona w kontekście społecznych reperkusji owej naukowej działalności i relacji akademickich badań z polityką. Stanowić będzie również próbę wprowadzenia omawianego problemu do polskiego obiegu naukowego w kontekście metodologii historii oraz historiografii. Zastosowanie metody analizy porównawczej oraz analizy źródłowej pozwoli na wypunktowanie najważniejszych nurtów badań nad pochodzeniem oraz funkcjonowaniem tej grupy etnicznej przy jednocześnie prowadzonej krytycznej analizie zastosowanej podczas nich metodologii naukowej.

Podstawą źródłową owych rozważań są zbiory Irlandzkiej Komisji Folkloru, a także raport Komisji ds. Koczownictwa z 1963 roku - stanowiący jeden z definiujących aktów prawnych związanych z funkcjonowaniem tej mniejszości w Irlandii, dający asumpt do badań nad językiem politycznej debaty i funkcjonowania naukowych teorii w społecznym obiegu. Ponadto jako źródła analizowane będą również prace naukowe powstałe w XX wieku, badające zagadnienia związane z historią i pochodzeniem Irish Travellers - pozwoli to w kompleksowy sposób omówić historię badań dotyczących tego tematu.

Analiza ma charakter historiograficzny, a artykuł nie dąży do udzielenia odpowiedzi na pytanie o pochodzenie grupy, lecz przedstawienie stanu badań oraz ich wpływu na polityczny dyskurs. W tym celu postawione zostały następujące pytania badawcze: $\mathrm{w}$ jaki sposób można zdefiniować tytułową grupę etniczną? Jaka jest jej relacja zarówno z irlandzkim państwem, jak i społeczeństwem i w jaki sposób zmieniała się ona na przestrzeni lat? Jakie było znaczenie polityczne i społeczne badań nad pochodzeniem grupy? Jakie teorie można wyszczególnić i jakiego rodzaju badania stanowiły podstawę do ich powstania? W jaki sposób można scharakteryzować ich naukowe, społeczne i polityczne znaczenie? Jakimi narzędziami i źródłami dysponują badacze akademiccy zgłębiający tę tematykę? Z jakiego rodzaju problemami metodologicznymi muszą się oni mierzyć? Czy możliwe jest prowadzenie badań bez powielania istniejących w środowisku akademickim założeń?

Aby odpowiedzieć na postawione pytania, konieczne jest zdefiniowanie zbiorowości, której dotyczyć będzie analiza. Irish Travellers to grupa etniczna stanowiąca około $1 \%$ populacji Irlandii, posiadająca charakterystyczne zwyczaje, język oraz kulturę odmienną od mieszkańców wyspy, którzy prowadzą osiadły tryb życia (McElwee, Jackson, Charles 2003: 104; Radzewicz 2016: 81). Została ona oficjalnie uznana za mniejszość etniczną Irlandii dopiero w 2017 r. Owo oficjalne potwierdzenie było kamieniem milowym w historii kontaktów Irish Travellers z irlandzkim państwem, zakończyło bowiem przede wszystkim trwającą kilka dekad politykę negacji odrębności grupy. Polityka ta zostanie poddana skrupulatnej analizie w niniejszym opracowaniu (Radzewicz 2016: 21-22).

W artykule używana będzie angielska nomenklatura. Funkcjonujące w polskim obiegu naukowym określenie Trawelerzy stanowi kalkę językową i jest wyjątkowo nieprecyzyjne. Irish Travellers stanowią bowiem jedną z kilku grup określanych w anglosaskim obiegu naukowym mianem Traveller. Funkcjonująca w języku polskim nazwa Cyganie również niesie za sobą pewną niejasność. Przywodzi bowiem na myśl skojarzenie z Romami lub Sinti. Sami członkowie omawianej grupy natomiast określają siebie jako Mincéirí, Pavees lub na Lucht Siúil (Radzewicz 2016: 79; Mayall 2004: 54-83), dlatego też te określenia będą stosowane w tekście jako synonimy.

W cenzusie ludności przeprowadzonym w roku 2016 przynależność do tej mniejszości zadeklarowało 30987 osób, co stanowi 0,7\% irlandzkiego społeczeństwa. Według danych organizacji zrzeszających Irish Travellers liczba członków ich społeczności szacowana jest na około 40 tys. osób (Radzewicz 2016: 25; Census 2016).

Odmienna kultura i język konstytuują odrębność owej grupy etnicznej. Jej najbardziej charakterystyczną cechą jest wędrowny tryb życia, choć sam ten zwyczaj nie decyduje o przynależności do grupy, na terenie Irlandii funkcjonują bowiem społeczności Irish Travellers prowadzące również osiadły tryb życia. Język, którym posługują się członkowie grupy, określany jest przez badaczy jako shelta, jednak sami użytkownicy używają nazwy gammon lub cant i unikają stosowania go w obecności osób spoza społeczności (McElwee, Jackson, Charles 2003: 104-105). 
Różnice kulturowe i odmienność stylu życia wpływają na wyobcowanie grupy i liczne problemy natury ekonomicznej i społecznej, z którymi muszą walczyć Irish Travellers. Dzieci pochodzące z tej grupy etnicznej często mierzą się z problemem wyrzucenia poza nawias systemu edukacji z uwagi na częste zmiany miejsca pobytu rodziny. Społeczność zmaga się również z różnymi przejawami dyskryminacji i nietolerancji (McElwee, Jackson, Charles 2003: 105; Radzewicz 2016: 25-26).

\section{Historyczne teorie dotyczące pochodzenia grupy}

Odmienność i wyobcowanie od wieków pobudzało wyobraźnię nie tylko osiadłych mieszkańców wyspy, ale również badaczy. Wiek XIX, a szczególnie jego ostatnie dekady i okres tzw. odrodzenia gaelickiego, dostarczył pierwszych tez na temat pochodzenia Irish Travellers (Burke 2009: 21-23).

Podwaliny badań stanowiły pierwsze zbiory i opracowania irlandzkich legend i mitów. Pochodzący z VIII w. tekst Lebor Gabála Érenn - Księga Inwazji, stanowiący podstawę źródłową wielu prac, przedstawiał legendarną wizję historii Irlandii, w której wyspa zasiedlana była przez kolejne fale toczących ze sobą boje najeźdźców (Burke 2009: 23). Pierwsi badacze doszukiwali się we wcześniej zamieszkujących Irlandię legendarnych grupach osadników przodków Irish Travellers. Najbardziej prominentnym przedstawicielem tego nurtu był profesor Eoin MacNeill - badacz historii, entuzjasta gaelickiego języka oraz zagorzały nacjonalista i późniejszy minister edukacji w rządzie Wolnego Państwa Irlandzkiego. W swojej pracy Phases of Irish History z wielkim zainteresowaniem analizował on jedną z grup mitycznych osadników, Fir-Bolgów, wysuwając teorię, jakoby mieli oni stanowić przodków współczesnych mu Irish Travellers (Burke 2009: 25-26).

W jaki sposób teoria ta kształtowała dyskurs na temat Irish Travellers? Wspólne celtyckie pochodzenie sytuowało Mincéirí jako członków irlandzkiego narodu. Osiadli mieszkańcy wyspy w nacjonalistycznej narracji stanowili grupę oddzielną od Brytyjczyków właśnie z powodu swego celtyckiego dziedzictwa, a wędrowna część społeczeństwa uznawana była za grupę bratnią, o zbliżonym pochodzeniu. Członkowie społeczności zostali pozbawieni prawa do odrębności - stanowili jedynie podgrupę osiadłych Irlandczyków. Choć teoria ta nie była poparta żadnymi badaniami i zrodziła się w głowach badaczy hobbystów, jej ślady nadal można odnaleźć w dyskursie naukowym (Crowley, Kitchin 2015: 163).

Równolegle kształtowała się druga grupa tez na temat pochodzenia Irish Travellers. Ich wspólnym mianownikiem jest założenie udziału jakiejś formy zewnętrznego ucisku w procesie wyłaniania się grupy z irlandzkiego społeczeństwa. Głęboko osadzone w fantazmacie nacjonalizmu, teorie te zakładały sztuczne wytworzenie osobnej grupy ludności w wyniku działań angielskiego najeźdźcy. Wyróżnić można kilka odmian tej wizji. Pierwsza zakłada, że Irish Travellers mogli być potomkami wysiedlonych przez Anglików mieszkańców północnej części wyspy, w rejonie tzw. Plantacji Ulsteru, lub nawet pozbawionych ziemi przywódców klanowych i irlandzkiej arystokracji (McElwee 2003: 106). Druga wariacja wskazuje, że grupa wyłoniła się podczas podboju Irlandii w czasach Olivera Cromwella z części ludności, która została pozbawiona uprawianej ziemi. Ostatni wariant, cieszący się największą popularnością, zakłada natomiast, że są oni potomkami mas ludności dotkniętych klęską Wielkiego Głodu w 1848 r., zmuszonych przez działania imperium brytyjskiego do wędrówki w poszukiwaniu środków do życia (McElwee, Jackson, Charles 2003: 106).

Wspólnym elementem wszystkich tych wizji jest przypisywanie mocy sprawczej w wytworzeniu się grupy działaniom brytyjskim, a co za tym idzie, przeniesienie odpowiedzialności za trudną sytuację społeczności na naturalnego wroga. Jednocześnie w tej grupie teorii Irish Travellers stali się ofiarami, odczuwającymi nadal skutki owej opresji, spod której irlandzki republikanizm i nacjonalizm pragnął wyzwolić społeczeństwo. Wskazywanie konkretnych historycznych wydarzeń jako źródła pochodzenia grupy jednocześnie odbierało jej prawo do wyprowadzania wywodu o swoim pochodzeniu sięgającego dawniejszych epok. Szła za tym również kolejna implikacja: grupa prowadząca niegdyś osiadły tryb życia może do niego powrócić. Obecny stan wiedzy historycznej każe podważać zasadność teorii o zabarwieniu nacjonalistycznym. Odkrywane są źródła dowodzące funkcjonowania tej grupy etnicznej przed wydarzeniami opisywanymi jako przyczyny jej wyodrębnienia (Crowley, Kitchin 2015: 31).

Bardziej holistyczne podejście do problemu odnaleźć można w kolejnej teorii głoszącej, że asumptem do wyodrębnienia się Irish Travellers były kwestie materialne. Badacze należący do tego nurtu skupiali się na 
przedstawieniu pochodzenia grupy w szerszym kontekście gospodarczo-społecznym, podając możliwe przyczyny wyodrębnienia się tej grupy, niezwiązane z działaniami Wielkiej Brytanii (Helleiner 1995; Helleiner 2000).

Historycznie jednym z głównych źródeł dochodu Irish Travellers było rzemiosło, a szczególnie naprawa i wytwarzanie metalowych przedmiotów codziennego użytku, takich jak garnki czy kotły. Stąd też ludność osiadła często stosowała wobec nich określenie „kotlarze” (ang. tinker). Bardzo długo stanowiło ono powszechnie stosowany i akceptowany przez badaczy synonim dla nazwy tej grupy etnicznej (MacNeill 1919: 75-78) mimo swojej wyjątkowej nieprecyzyjności, a także - co szczególnie podkreślane jest przez współczesnych badaczy oraz samych Irish Travellers - pejoratywnych konotacji.

Według teorii potrzeb ekonomicznych na wędrowny styl życia grupy wpłynęło wiele czynników. Jednym z najważniejszych było niskie zapotrzebowanie na ciągłą pracę rzemieślników dla jednej społeczności. Z uwagi na dużą trwałość wytwarzanych obiektów oraz sezonowe zapotrzebowanie na naprawy rzemieślnicy musieli stale zmieniać miejsca pobytu i przenosić się od społeczności do społeczności, powracając dopiero po jakimś czasie, by dokonać następnych drobnych napraw. Kolejnym ważnym argumentem była specyfika irlandzkiej agrokultury, dla której charakterystyczny był wypas bydła przy jednoczesnym czasowym prowadzeniu koczowniczego tryb życia - praktyka ta nosiła nazwę booleying. Analizując owe gospodarcze uwarunkowania, można zauważyć, że wykształcenie się na terenie Irlandii osobnej społeczności nieprowadzącej osiadłego trybu życia przestaje stanowić znaczące odejście od normy. Tradycja wypasu została w Irlandii porzucona na początku XX wieku wraz z wprowadzeniem nowych rozwiązań technicznych pozwalających na usprawnienia w zakresie hodowli bydła (Castello 2016: 66). Równolegle rozpoczął się również proces zmian w postrzeganiu wędrownej społeczności przez osiadłą część społeczeństwa (McElwee, Jackson, Charles 2003: 108; Crowley 2005: 129). Tak sformułowana teoria o pochodzeniu grupy zawiera jednak niebezpieczną pułapkę: myślenie o Irish Travellers jako o rzemieślnikach i traktowanie tych członków grupy, którzy nie zajmowali się rzemiosłem, jako swego rodzaju odstępstwa od normy (Bhreatnach 2007: 31).

Jedną z najpopularniejszych hipotez na temat pochodzenia społeczności była jednak ta sformułowana w latach 60. XX wieku przez Sharonn i George’a Gmelchów. Według tych badaczy wyłonienie się grupy nastąpiło w wyniku długotrwałego procesu postępującego wykluczenia społecznego różnorodnych grup ludności, które utworzyły nomadyczną społeczność, zmuszaną do stałego przemieszczania się (Gmelch 1985; Gmelch, Gmelch 1976). Jej członkami mieli być: wędrowni rzemieślnicy, przestępcy uciekający przed prawem, prostytutki oraz żebracy i inne osoby wyrzucone poza nawias społeczny (Bhreatnach 2007: 31). Badania Gmelchów, choć przełomowe jak na swoje czasy, wprowadziły do obiegu naukowego wiele niepopartych źródłami koncepcji i nadinterpretacji. Gmelchowie na podstawie bardzo ograniczonego materiału stawiali tezy dotyczące całej omawianej społeczności. Bazowali głównie na danych zebranych na początku XX wieku przez Komisję Folkloru (Bhreatnach 2007: 32; Crowley, Kitchin 2015: 169). Gmelchowie na podstawie stosunkowo małego zbioru źródeł, o dość stronniczym charakterze tworzyli niezwykle rozbudowane tezy. Z kilku relacji ludności osiadłej wysnuwali wnioski na temat nie tylko funkcjonowania wyizolowanej grupy, ale również stosunku ogółu irlandzkiego społeczeństwa do niej (Bhreatnach 2007: 32). Anegdotyczne dowody w badaniach Gmelchów stanowiły wystarczającą podstawę do tworzenia generalizacji na temat całej zbiorowości - jak to np. miało miejsce w przypadku opisów zwyczajów związanych ze spożyciem alkoholu (Gmelch, 1985: 101). To również George Gmelch odpowiedzialny był za wprowadzenie do obiegu naukowego rozgraniczenia pomiędzy przydatnym społecznie stereotypowym „kotlarzem” a zbędnym wędrującym członkiem społeczności Irish Travellers (Gmelch 1985: 42-53).

\section{Problemy metodologiczne}

Znaczenie społeczne omówionych badań było ogromne: utrwalały one negatywny wizerunek grupy, jednocześnie dowodząc istnienia wrogości i niechęci osiadłych mieszkańców wyspy w stosunku do wędrownych Irlandczyków. Dodatkowo wyniki owych analiz ekstrapolowano również na przeszłość, dowodząc, że niechęć społeczna odczuwana w połowie wieku XX charakteryzowała również stosunki tych dwóch grup w wiekach wcześniejszych. Dowodzenie nieprzystosowania społecznego oraz wytworzenia się grupy 
w wyniku postępującej marginalizacji wyrzuconych poza nawias społeczny jednostek stanowiło podstawę do postrzegania jej jako wymagającej pomocy państwa. U podstaw badań Gmelchów, które obecnie odrzuca większość irlandzkich badaczy zajmujących się tą problematyką, oraz innych wywodów na temat pochodzenia grupy leżała wadliwa metodologia. W związku z tym omówienie pojawiających się na tym polu problemów badawczych wydaje się zasadne.

W dużej mierze początkowe badania prowadzone na ten temat łączyły cele naukowe z politycznymi, opierając się na nacjonalistycznej i republikańskiej ideologii. Dodatkowo przedstawiana wizja historii w znacznym stopniu opierała się na wyobrażeniach o idyllicznej celtyckiej przeszłości oraz negatywnym stosunku do brytyjskiego ciemiężyciela. Badania te nie tworzyły również precyzyjnej definicji grupy, co z kolei prowadziło do błędnych uogólnień. Czy wszyscy wędrowni rzemieślnicy stanowili część omawianej grupy i czy w związku z tym odnajdywane w źródłach historycznych frazy dotyczące „kotlarzy” koniecznie muszą się odnosić właśnie do Irish Travellers? Odpowiedź na to pytanie jest kluczowa dla wszelkich prób periodyzacji dziejów grupy i wywodów o pochodzeniu tej społeczności. Czy elementem konstytuującym odrębność było prowadzenie koczowniczego trybu życia? Czy w związku z tym można wykluczyć ze zbiorowości osiadłych Irish Travellers (McElwee, Jackson, Charles 2003: 105; Gmelch 1985: 105; Bhreatnach 2007: 30-32)?

Poza tymi kwestiami spornymi występował również zaawansowany problem stronniczości analizowanych źródeł. Kultura społeczności przekazującej swoje wzorce, tradycje oraz opowieści w sposób ustny wykluczała możliwość zbadania i skatalogowania źródeł pisanych. Na początku XX wieku nie prowadzono również wywiadów wśród samych Irish Travellers. Zainteresowanie lingwistów budził język shelta, jednak wyłącznie w sensie strukturalnym - badaczy nie zajmowały przekazywane przy jego użyciu historie i narracje (Burke 2009: 24). W efekcie osoby prowadzące badania musiały oprzeć swoje analizy na przekazach tworzonych jedynie przez część społeczeństwa prowadzącą osiadły tryb życia.

Podstawowym źródłem do tego rodzaju badań stała się, wspominana już wcześniej, kolekcja stworzona przez Komisję Folkloru. Zebrane informacje stanowiły podstawę większości prac naukowych na ten temat, warto więc dokonać analizy metodologii tworzenia owej kolekcji. Badania prowadzono od lat 30. XX wieku w formie zarówno wywiadów antropologicznych, jak i poprzez kwestionariusze (Briody 2016: 260-267). Stworzona w ten sposób kolekcja stanowi do dziś niezastąpione źródło informacji na temat zwyczajów irlandzkich rolników, życia społecznego oraz historii materialnej Irlandii na początku XX wieku. Warto jednak podkreślić, że choć jest to bezapelacyjnie wspaniałe źródło dla szeregu działań naukowych, badania społeczności Irish Travellers, opierające się w dużej mierze na tym materiale, muszą zostać zakwestionowane.

Ze względu na naturę prowadzonych wywiadów relacje dotyczące życia na Lucht Siúil przedstawiały jedynie zewnętrzne spojrzenie na tę kwestię członka innej społeczności o odmiennej kulturze (IFC, 1952, Tinkers Questionnaire). Żaden kwestionariusz na ten temat nie został nigdy wypełniony przez osobę prowadzącą wędrowny tryb życia. Przekazywano w nich mity i nierzadko szkodliwe przekonania, wynikające z niewiedzy lub niechęci. Dane te następnie traktowane były przez pokolenia naukowców jako podstawa źródłowa - w ten sposób wprowadzali oni tezy z obiegu społecznego do naukowego. Informacje z kwestionariusza postrzegano jako dowody i twarde dane, a nie wycinek rzeczywistości i fragment narracji innej grupy. Mity i stereotypy przeniknęły niezauważenie do sfery nauki, stając się w przyszłości również podłożem dla działań irlandzkiego rządu (Nochlin, Garb 1996: 8).

Jednocześnie problem braku źródeł stanowi poważną przeszkodę w nowych badaniach. Bogactwo Kolekcji Folkloru nie może być zignorowane i zupełnie odrzucone, stanowi bowiem, mimo swych wad, skarbnicę wiedzy na temat przekonań i imaginarium części irlandzkiego społeczeństwa. Dlatego też warta odnotować potrzebę stworzenia podobnego zbioru narracji Irish Travellers, które mogłyby zostać skonfrontowane z wizją osiadłej części społeczeństwa (Bhreatnach, Bhreatnach 2008: 3-5). Tego rodzaju działalność prowadzona jest obecnie przez organizacje Pavee Point oraz Irish Travellers Movement, które podkreślają potrzebę przedstawienia historii samych Irish Travellers, ich własnymi słowami, czerpiąc z ich odmiennej wrażliwości i kultury (Fay 1992). W ten sposób rola badaczy jest redefiniowana. Zachodzi potrzeba przeistoczenia się z zewnętrznego obserwatora w swego rodzaju mediatora, pomagającego w przedstawieniu obrazu społeczności samym jej członkom (Crowley, Kitchin 2015: 161). 


\section{Znaczenie społeczne i polityczne badań}

Potrzeba dostarczenia grupie narzędzi do prowadzenia debaty z przedstawicielami nie tylko osiadłej społeczności, ale także irlandzkiego państwa stała się szczególnie ważna w kontekście działań polityków i prób rozwiązania „problemu Irish Travellers”, który stopniowo narastał od czasu powstania Wolnego Państwa Irlandzkiego w latach 20. XX wieku. Dla wyzwalającego się spod wpływów Wielkiej Brytanii narodu niezwykle ważna była walka z ubóstwem, analfabetyzmem i wzniesienie Irlandii na wyższy poziom cywilizacyjny (Bhreatnach 2006: 82-83). Grupa Irish Travellers zaczęła być postrzegana jako przeszkoda na drodze do tego celu.

Na początku lat 60. XX wieku Irlandia znalazła się w kryzysie. Niezadowolenie społeczne rosło, a państwo nie radziło sobie z transformacją. Nadzieje związane z budową niepodległej państwowości nie zostały zrealizowane. Rosła emigracja, państwo irlandzkie próbowało walczyć z pojawiającymi się problemami za pomocą serii raportów o stanie gospodarki i społeczeństwa, które miały zdiagnozować podstawowe problemy toczące irlandzką wspólnotę (Crowley 2005: 133). Jednym z takich „problemów” wymagających, zdaniem irlandzkiego rządu, rozwiązania była kwestia Irish Travellers. Sprawa ta miała zostać zbadana przez grupę ekspertów. Nie było wśród nich żadnego przedstawiciela badanej społeczności (COI 1963: 134). Stworzony przez Komisję ds. Koczownictwa raport stał się jednym z najważniejszych dokumentów w tej sprawie, na długie lata kształtując polityczny i społeczny dyskurs dotyczący funkcjonowania wędrownej mniejszości w irlandzkim społeczeństwie.

Omawiał on szczegółowo warunki życia Irish Travellers, kładąc szczególny nacisk na kwestie zdrowia i edukacji. Zwracano uwagę na wykluczenie z systemu szkolnego dzieci pochodzących z tej społeczności i powielanie wzorców przekazywanych przez rodziców. Jednocześnie w raporcie pojawiały się wyjątkowo kategoryczne pejoratywne opisy członków grupy - które na lata stały się elementem zarówno społecznego, jak i naukowego dyskursu. Po publikacji raportu zdecydowanie zwiększyła się ingerencja irlandzkiego państwa w życie społeczności. Próbowano unormować udział dzieci Irish Travellers w systemie edukacji, a także kwestie związane z opieką medyczną. Autorzy raportu rekomendowali przymusową asymilację grupy do irlandzkiego społeczeństwa. Cel ten miał być osiągnięty poprzez penalizację wędrownego stylu życia (COI 1963: 28, 106). Jedną z rekomendowanych metod miało być odbieranie dzieci rodzinom i umieszczanie ich w państwowych szkołach, by nie dopuścić do przekazania nomadycznych wzorców zachowania (COI, 1963: 68).

Raport $\mathrm{w}$ rozdziałach dotyczących pochodzenia grupy cytował zarówno teorie związane z potrzebami ekonomicznymi, jak i te nawiązujące do nacjonalistycznej wizji historii, przypisując wyłonienie się społeczności działaniom brytyjskim. W ten sposób teorie z przełomu XIX i XX wieku zostały wykorzystane przez aparat państwowy w celu poparcia tez o potrzebie pomocy dla owej grupy etnicznej. Jednocześnie podkreślano, że Irish Travellers wywodzą się od członków osiadłej irlandzkiej społeczności, legitymizując przymus asymilacji i powrót wędrujących Irlandczyków do osiadłego trybu życia. (COI 1963: 34-35).

Relacja polityki z nauką nie ograniczała się jedynie do czerpania przez członków Komisji z dorobku pierwszych badaczy tego zagadnienia. Sam raport również stał się źródłem - dokumentem cytowanym przez przyszłych badaczy. Stanowił między innymi jedną z podstaw badań Gmelchów. Zainteresowanie badaczy łączyło się również ze wzmożonymi działaniami państwa w tej dziedzinie i zapotrzebowaniem na stworzenie teoretycznych, naukowych podstaw do rządowych działań związanych z przymusową asymilacją. Tezy stawiane przez Gmelchów i innych badaczy z tego nurtu zdawały się potwierdzać potrzebę systemowej pomocy dla Irish Travellers. Założenia przyjęte w tym okresie były następnie powielane w środowisku naukowym (Crowley, Kitchin 2015: 160-161; McCarthy 1972). Dopiero pojawienie się nurtu badań postkolonialnych i zastosowanie jego narzędzi w badaniu społeczności Irish Travellers pozwoliło przełamać owe stereotypy (Burke 2009: 27).

Warto podkreślić uniwersalność opisywanego zjawiska. Wnioski płynące z analizy przypadku Irish Travellers w Irlandii z powodzeniem można zastosować również do omawiania historycznych źródeł wykluczenia innych mniejszości i grup etnicznych. Niezależnie od regionu i miejsca, niebezpieczne wykorzystanie teorii naukowych jako argumentacji wspierającej wprowadzanie aktów legislacyjnych wpływających na funkcjonowanie marginalizowanych grup jest faktem. Badania nad owymi mechanizmami mogą skutkować 
większą samoświadomością środowiska akademickiego, a co za tym idzie, również zwiększeniem poczucia odpowiedzialności za głoszone tezy.

Wprowadzane do obiegu naukowego teorie o pochodzeniu grupy oraz materiały źródłowe, takie jak kwestionariusze Komisji Folkloru, na długie lata ukształtowały nie tylko paradygmat naukowy, ale również język debaty politycznej. Każda z omawianych wizji przeszłości miała znaczenie społeczne i kształtowała zbiór wyobrażeń utrwalający wizję grupy etnicznej Irish Travellers. Metodologia badań w pośredni sposób wpływała na postępującą marginalizację grupy, pogłębiając proces społecznego wykluczenia. Zmiana w podejściu środowiska naukowego do tego problemu jest stosunkowo nowym trendem. Jej efekty zostaną wykorzystane w badaniach naukowych dopiero w nadchodzących latach, dzięki pojawieniu się nowych materiałów źródłowych w postaci zbiorów historii mówionej Irish Travellers czy wywiadów antropologicznych z członkami społeczności. Również udział samych Pavees, zrzeszonych w różnego rodzaju organizacjach, sprawia, że monopol pochodzącego wyłącznie ze społeczności osiadłej środowiska naukowego został złamany. Usystematyzowanie i opracowanie nowych materiałów źródłowych oraz zastosowanie do tej pory nieaplikowanej metodologii łączącej zarówno zbiory narzędzi charakterystycznych dla badania mobilności społecznej, struktur klanowych, społecznej pamięci, jak i badań nad tożsamością i płcią kulturową pozwoli na osiągnięcie przełomowych wyników analiz. Jednocześnie utrzymanie powiązania nauki i polityki być może pozwoli również zmodyfikować rządową strategię pomocy mniejszości Irish Travellers.

\section{Bibliografia}

Bhreatnach A., Bhreathnach C. (2008), Portraying Irish Travellers: Histories and Representations. Cambridge: Cambridge Scholars Press.

Bhreatnach A. (2006), The 'itinerant problem: The attitude of Dublin and Stormont governments to Irish Travellers, 1922-60. „Irish Historical Studies” 35 (137): 81-98.

Bhreatnach A. (2007), 'Confusing origins and histories: The case of Irish Travellers'. „Irish Journal of Anthropology” 10 (1): 30-35.

Briody M. (2016), The Irish Folklore Commission 1935-1970 History, ideology, methodology. Helsinki: Finnish Literature Society. Press.

Burke M. (2009), 'Tinkers': Synge and the Cultural History of the Irish Traveller. Oxford: Oxford University

Castello E. (2016), Seasonal Management of Cattle in the Booleying System: New Insights from Connemara, Western Ireland [w:] M. O'Connell, F. Kelly, J.H. McAdams (red.). Cattle in Ancient and Modern Ireland: Farming Practices, Environment and Economy. Newcastle upon Tyne: Cambridge Scholars Publishing.

Central Statistics Office, Census 2016 Profile 8 Irish Travellers, Ethnicity and Religion, October 2017.

Crowley U. (2005), Liberal rule through non-liberal means: the attempted settlement of Irish Travellers (1955-1975). „Irish Geography” 38 (20): 128-150.

Fay R. (1992), Minorisation of Travelling Groups and Their Cultural Rights - The Case of Irish Travellers. Dublin: Pavee Point Publications.

Gmelch G. (1985), The Irish Tinkers: the Urbanization of an Itinerant People. Illinois: Waveland Press.

Gmelch S., Gmelch G. (1976), The emergence of an ethnic group: The Irish tinker. „Anthropological Quarterly" 49: 225-38.

Government of Ireland (1963), Report of the Commission on Itinerancy. Dublin: Stationery Office.

Helleiner J. (1995), Gypsies, Celts and tinkers: colonial antecedents of anti-traveller racism in Ireland. „Ethnic and Racial Studies" 18 (3): 532-54.

Helleiner J. (2000), Irish Travellers: Racism and the Politics of Culture. Toronto: University of Toronto Press.

Irish Folklore Commission (IFC) (1952), Tinkers Questionnaire. Department of Irish Folklore, University College Dublin.

Kitchin R., Crowley U. (2015), Academic 'truth' and perpetuation of negative attitudes and intolerance towards Travellers in Contemporary Ireland [w:] I. Honohan, N. Rougier (red.), Tolerance and Diversity in Ireland, North and South. Manchester: Manchester University Press: 153-170. 
MacNeill E. (1919), Phases of Irish History. Dublin: M.H. Gill.

Mayall D. (2004), Gypsy Identities 1500-2000: From Egipcyans and Moon-men to the Ethnic Romany. London: Routledge.

McCarthy P. (1972), Itinerancy and Poverty: A Study in the Sub-Culture of Poverty. Dublin: University College Dublin.

McElwee N., Jackson A., Charles G. (2003), Towards a Sociological Understanding of Irish Travellers: Introducing a People. „Irish Journal of Applied Social Studies” 4 (11): 103-120.

Nochlin L., Garb T. (1996), The Jew in the Text: Modernity and the Construction of Identity. London: Thames and Hudson.

Radzewicz E. (2016), Prawo do drogi. Przypadek Trawelerów z miasta Galway. „Studia Migracyjne Przegląd Polonijny" 4 (162): 77-95. 